\title{
Archaeological Survey of the McGee Ranch Vicinity, Hanford Site, Washington
}

\author{
H. A. Gard \\ R. M. Poet
}

September 1992

Prepared for the U.S. Department of Energy under Contract DE-AC06-76RLO 1830

Pacific Northwest Laboratory

Richland, Washington 99352 


\section{EXECUTIVE SUMMARY}

In response to a request for a cultural resources review from Westinghouse Hanford Company for the Action Plan for Characterization of McGee Ranch Soil, HCRC\#91-600-012, Pacific Northwest Laboratory's Hanford Cultural Resources Laboratory (HCRL) conducted an archaeological survey of the McGee Ranch vicinity, located in the northwest portion of the Hanford Site. Staff members covered $8.4 \mathrm{~km}^{2}$ and recorded 42 cultural resources; 22 sites, and 20 isolated artifacts. Only 2 sites and 3 isolates were attributed to a prehistoric Native American occupation. The historic sites date from the turn of the century to the 1940s and are representative of the settlement patterns that occurred throughout the Colurnbia Basin.

In addition to an archaeological pedestrian survey of the project area, we conducted literature and records searches and examined available aerial photographs. Records kept at HCRL were reviewed to determine if any archaeological survey had been conducted previously within the project area. Although no survey had been conducted, portions of the area adjacent to project boundaries were surveyed in 1988 and 1990. During those surveys, historic and prehistoric cultural resources were observed, increasing the possibility that similar land usage had taken place within the current project boundaries. Literature searches established a general historical sequence for this area. Aerial photographs alerted researchers to homesteads and linear features, such as roads and irrigation ditches, that might not be apparent from ground level.

Of the $\mathbf{2 2}$ sites recorded, 8 are recommended as potentially significant. Both prehistoric sites are important, providing evidence of rarely reported inland exploitation of resources between 4500 and 2500 B.P. Should mitigation of these sites prove necessary, their limited areal extent should make this task fairly simple. Recommended mitigation would include surface collection and field documentation.

The 6 potentially significant historic sites were selected because they are representative of their occupation period and have the potential to contribute new information regarding these eras. Two sites are representative of the earliest Euroamerican settlement of the Columbia Basin, which did not occur until the turn of the century. The remaining sites are remnants of the Depression era. Very little archaeological research has been conducted on the Depression era, as it has only recently been considered historic. In addition, few dug-outs dating to this period of 
economic decline remain intact. These dug-out sites sites meet criteria for nomination to the National Register of Historic Places as representative of a type of architecture and because of their potential to provide scientific information important to an understanding of regional history. 


\section{CONTENTS}

EXECUTIVE SUMMARY.........................................................................................

INTRODUCTION

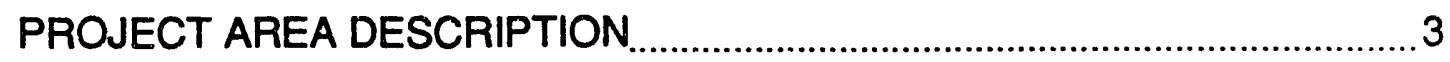

METHODS

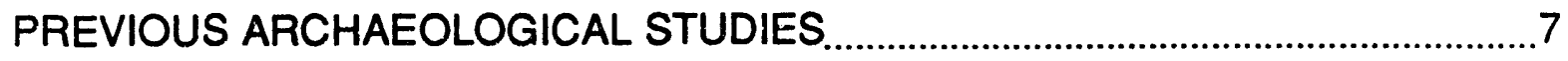

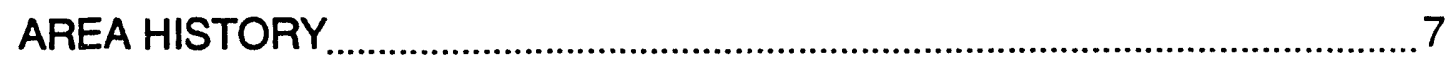

CULTURAL RESOURCES OBSERVED...............................................................13

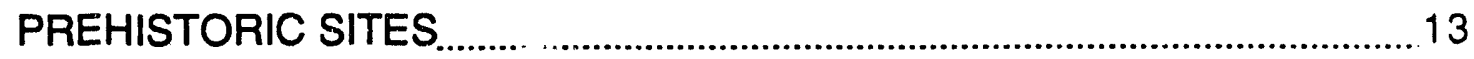

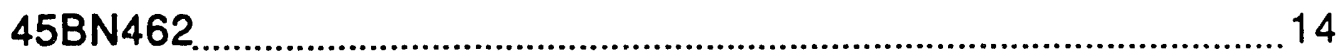

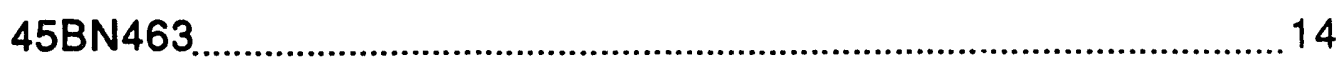

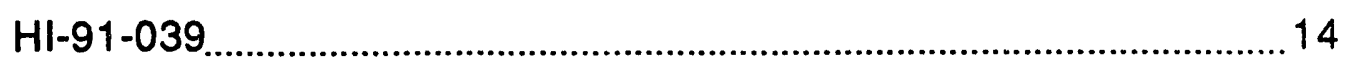

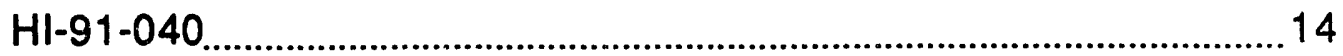

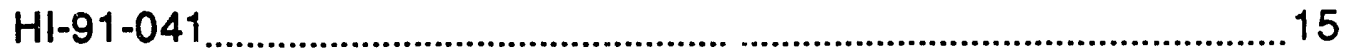

HISTORIC SITES

H3-24

H3-30

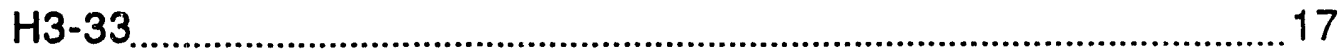

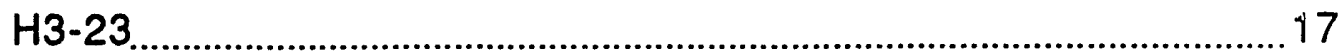

H3-25

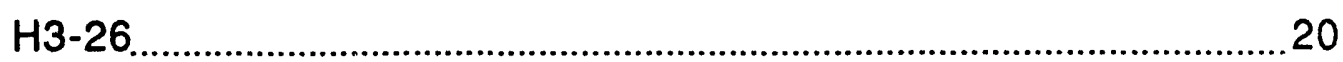

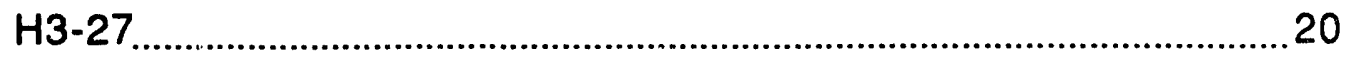

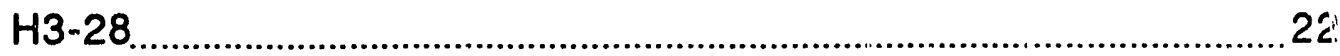

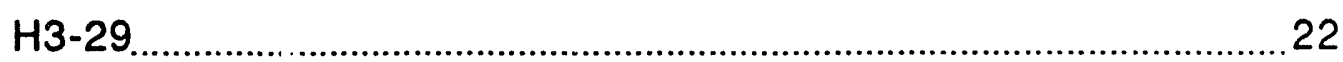

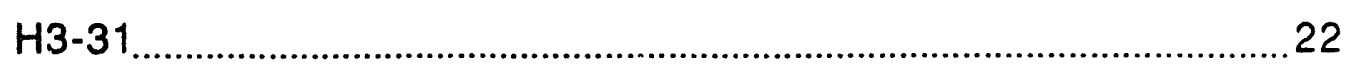

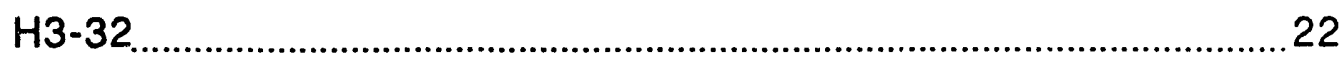

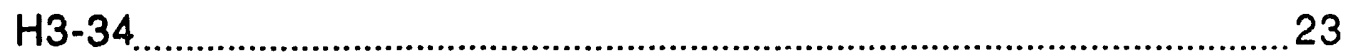

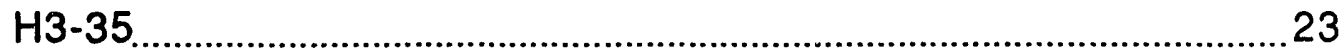




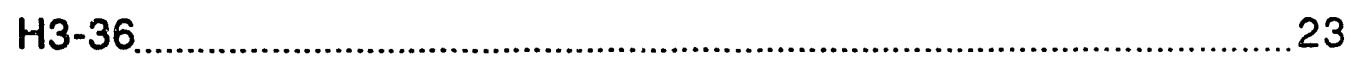

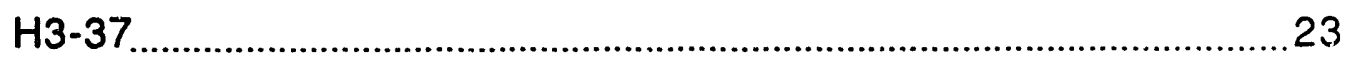

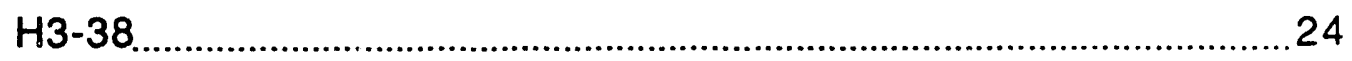

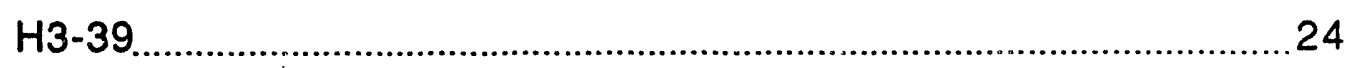

H3-40

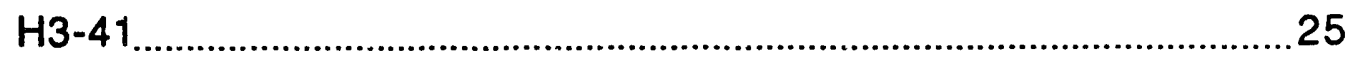

H3-42

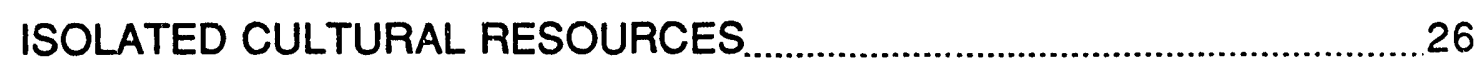

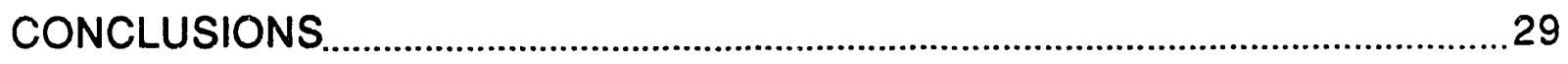

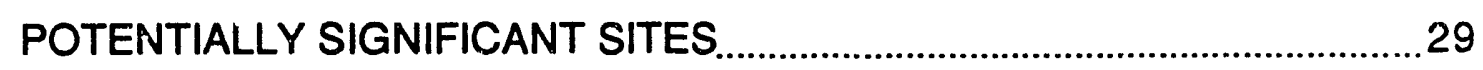

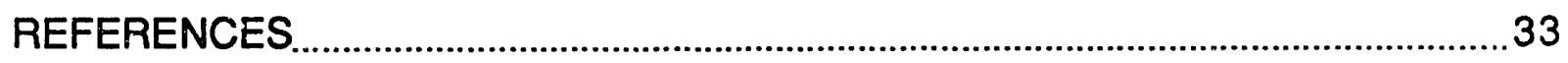




\section{FIGURES}

1 Location of the McGee Ranch Project Area ......................................................... 2

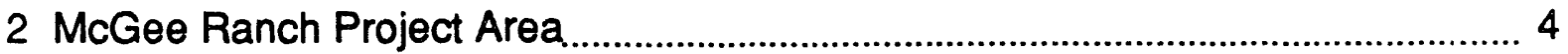

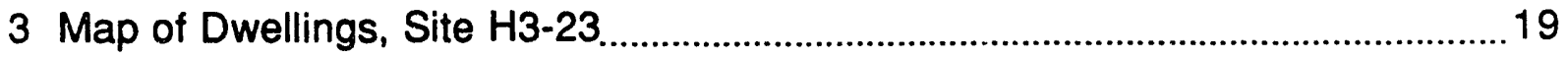

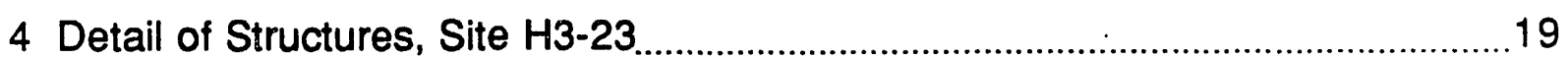

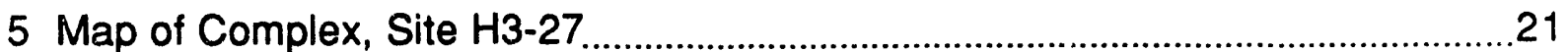

\section{TABLES}

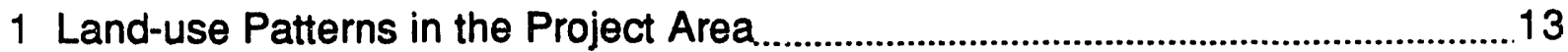

2 Isolated Artifacts Recorded W:ithin the McGee Ranch Project Area ......................27 


\section{INTRODUCTION}

The McGee Ranch archaeological p' oject was initiated by Pacific Northwest Laboratory (PNL) at the request of Westinghouse Hanford Company for a cultural resources review. An area of approximately $3.5 \mathrm{sq}$ miles $\left(8.4 \mathrm{~km}^{2}\right)$ west of the Yakima Barricade on the Hanford Site is being considered as a source of fine-textured soils (Figure 1) to construct multi-layer closure covers for various waste sites, including sites covered under the Resource Conservation and Recovery Act (RCRA) and the Comprehensive Environmental Response, Compensation, and Liability Act (CERCLA) projects and the solid waste landfill. The first phase in the soil-source identification and characterization process is surficial geologic mapping and sampling, which includes drilling boreholes to gauge deposit depth and collect subsurface sediments. If appropriate soils are located, then borrow sites will be developed.

Because these characterization studies, which entail excavating boreholes and test trenches and developing large borrow pits, may potentially impact significant cultural properties, a cultural resources review was required. Section 106 of the National Hisioric Preservation Act (NHPA) (16 USC 470 et seq.) specifies that federal land managers must take into consideration the impact of any undertaking on significant historic properties. Historic properties are archaeological, historic, or cultural sites that meet criteria for nomination to the National Register of Historic Places. If no inventory of historic properties has been conducted in the area of potential effect, such an inventory is to be conducted before initiating the undertaking.

The original request for cultural resources review included only selected sampling sites within the entire project area; however, after consultation with Westinghouse Hanford project managers, it was agreed that the most efficient method of conducting the review would be to survey the entire project area. At this early phase of project development, plans could be altered to avoid significant properties, thus saving the expense of costly mitigation procedures. Additionally, if significant properties are located that cannot be avoided, then time is available to develop the most appropriate mitigation measures without holding up construction schedules. Large-scale surveys also allow for identifying patterns and relationships among resources, which aids in interpretation. Singly identified resources are frequently considered significant on the basis of their uniqueness. When entire areas are inspected, comparable or redundant sites are frequently found, making it possible to 


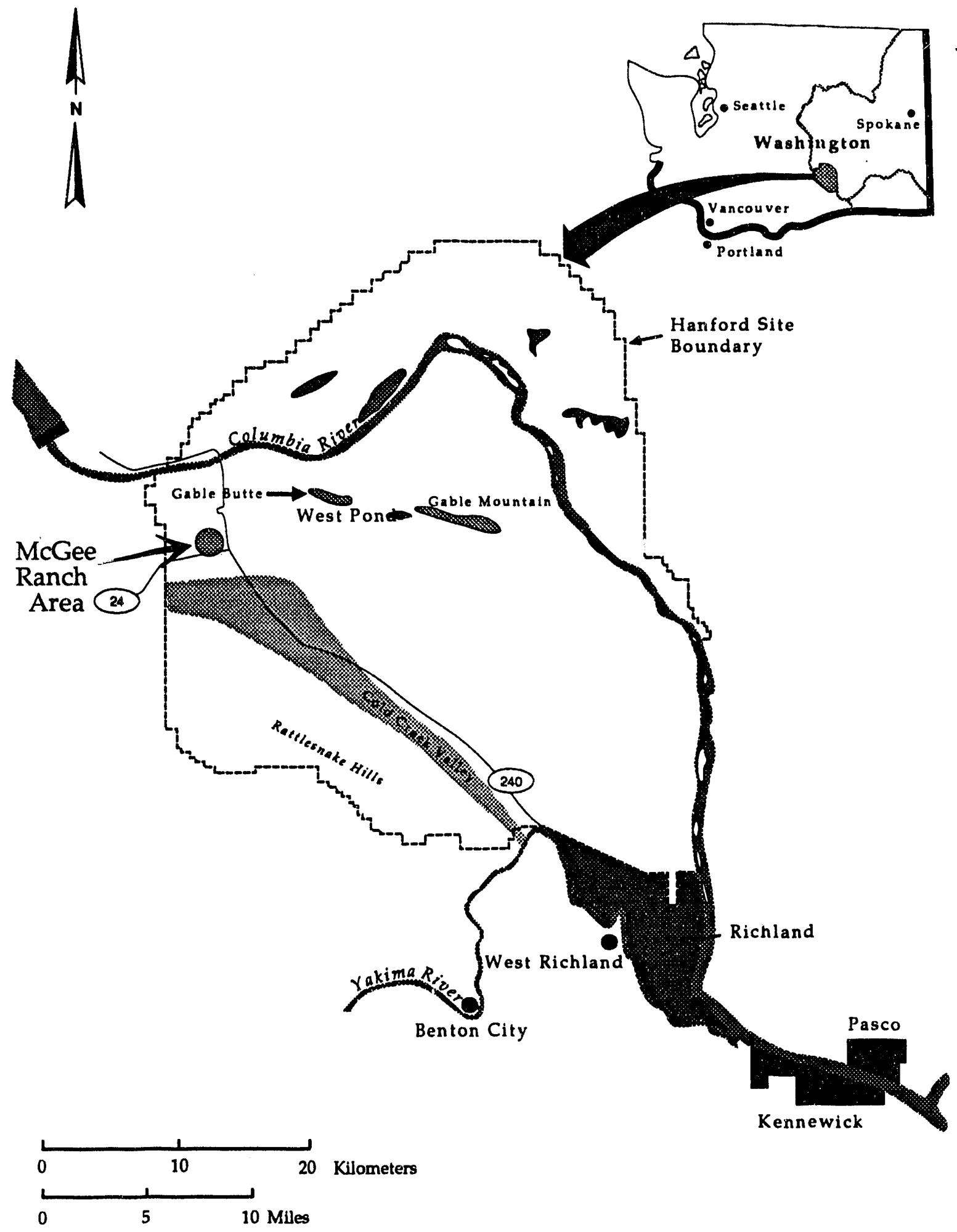

FIGURE 1. Location of the McGee Ranch Project Area 
select only the most intact or representative sites of a particular type for further consideration under NHPA.

Archaeological pedestrian survey by Hanford Cultural Resources Laboratory staff (HCRL) commenced on 1 October 1991, and fieldwork was completed on 19 November 1991. Records research, site form preparation, and document submission to the State Historic Preservation Office (SHPO) continued throughout the remainder of November and December.

\section{PROJECT AREA DESCRIPTION}

Encompassing an area of $8.4 \mathrm{sq} \mathrm{km}(840 \mathrm{ha})$, or $3.23 \mathrm{sq}$ miles $(2,067.2$ acres) the project area's topography is characterized by broad, rolling inland flats dissected by numerous northwest/southeast-trending dry washes, which occur in greater frequency in the eastern portion of the project area (Figure 2). The washes do not show any signs of recent water flow, having flat bottoms, indicating substantial aeolian deposition. Available water is restricted to three currently capped artesian wells, although small springs may be present during the wet seasons. From the eastern edge of the project area, it is approximately $3 \mathrm{~km}$ to the Cold Creek drainage system.

Soils in the area are fine glacio/fluvial sediments mixed with unsoited angular inclusions grading from pea gravels to large granitic erratics. A wide variety of rocks are present in these deposits, including slates, basalts, quartz, and granite.

The vegetation shows a strong demarcation between historic plowed fields and relatively undisturbed ground. In the areas modified by farming practices, Russian thistle (Salsoa kall) and cheatgrass (Bromus tectorum) are the dominant plant species. Undisturbed areas are characterized by sagebrush (Artemisia tridentata), spiny hopsage (Atriplex spinosa), and bluegrass (Poa sandbergii). Other plant species noted in the project area include rabbit brush (Chrysothamnus nauseosus) and tumble mustard (Sisymbrium altissimum).

Mule deer (Odocoileus hemionus), coyote (Canis latrans), black-tailed jackrabbit (Lepus californicus), white-tailed jackrabbit (Lepus townsendi), bobcat (Lynx rufus), and various birds and small rodents are common in the area. During the survey, two curlew (Numenius americanus) nests with unhatched eggs were also noted. 
This report describes the methods used to conduct the cultural resources review of the McGee Ranch area, discusses area history and cultural resources observed during the review, and presents conclusions and recommendations based on this initial review.

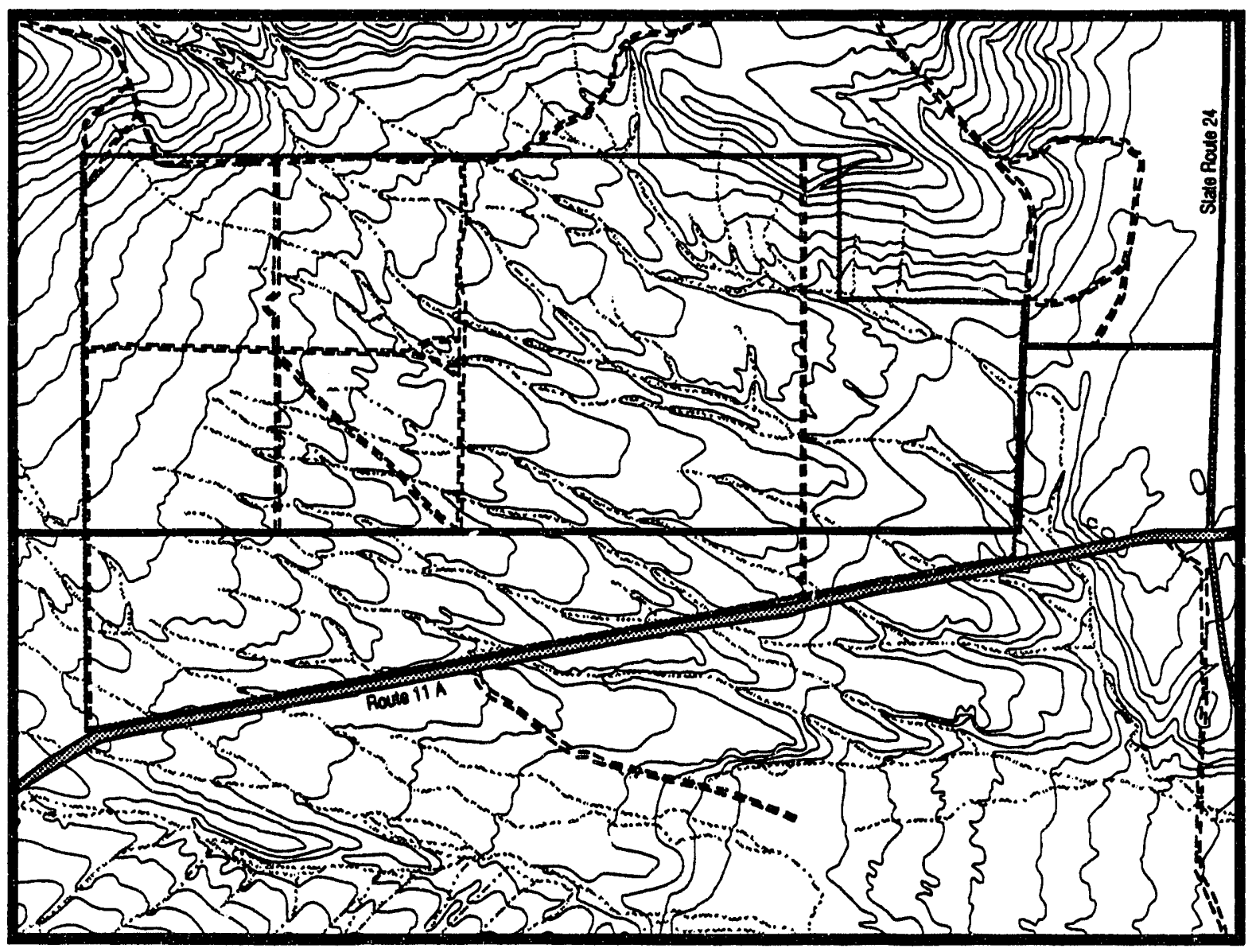

ElGURE2. McGee Ranch Project Area. Township 13 North, Range 24 East. Scale is $1: 2400$ 


\section{METHODS}

This study consisted of literature and records reviews and an archaeological pedestrian survey. Procedures used followed specifications outlined in the Hanford Cultural Resources Management Plan, Section 3.1.1. (Chatters 1989, pp 3.2-3.12).

The literature review entailed a search of the HCRL site survey files and archaeological site records. These records contain maps of previously surveyed areas and all recorded archaeological and historical sites. A library search was also conducted to find literature pertaining to local history. A records search of land deeds has been initiated at the Benton County Courthouse.

The archaeological survey consisted, first, of using aerial photographs to identify likely locations of homesteads and other historical features such as roads and irrigation ditches. Staff members then searched the land surface in parallel transects spaced a maximum of $20 \mathrm{~m}$ apart and recorded all observations. An archaeological site or isolate form was completed for each artifact or site discovered. Sites were described, sketch mapped, and photographed. Artifacts important to site interpretation were also photographed; three diagnostic artifacts were collected for analysis in the laboratory. No excavations of any kind were conducted.

Completed archaeological site forms were submitted to the Washington Office of Archaeology and Historic Preservation (OAHP) in Olympia, which maintains a complete file of prehistoric and historic archaeological sites for the state of Washington. Site numbers assigned by the OAHP begin with the designation "45BN" (meaning Washington, Benton County) for archaeological sites, followed by a number indicating sequence of discovery. For historic sites, the state substitutes the letter designation for county with a numeral indicating the county's place in alphabetical order. (Benton is 3.) For clarity, we add " $H$ " to these designations to identify them as historic. Isolated artifacts are not registered with the OAHP and are, therefore, assigned HCRL numbers, which begin with "HI" for Hanford isolate, followed by the year of discovery and a number for the order of discovery. All survey records, photographs, and site forms are curated by the HCRL. 


\section{PREVIOUS ARCHAEOLQGICAL STUDIES}

No previous archaeology has been done within the current project boundaries (Figure 1). The area just east of the current project, however, was reviewed in 1988 and 1990, resulting in the recording of several prehistoric and historic sites, which indicated a high probability of finding vestiges of prehistoric and historic use within the current project area.

\section{AREA HISTORY}

The history of the Columbia Basin revolves around the Columbia River. For the 10,000 years before Captain Robert Gray crossed the bar at the mouth of the river in 1792, the Columbia River served as the focal point of transportation and economy for Native Americans in the region. Although trade between the native population along the lower Columbia and the incoming Europeans quickly followed Gray's visit, Lewis and Clark, in 1805, were the first recorded white men to visit the Columbia Basin. They were followed soon after by trappers and other explorers. The Northwest Company established Spokane House in 1807 to act as a trade center. Between 1807 and 1811, David Thompson of the Northwest Company made many excursions around the region, recording his travels for posterity. In 1811, John Jacob Astor sent two teams of fur trappers to the Northwest. One group arrived at mouth of the Columbia from the sea, establishing Astoria. The other group traveled overland, arriving much later. Information they accumulated paved the way for the construction of Fort Okanogan. Several other forts and trading outposts were also built in subsequent years.

By the 1830 s much of the West was mapped by the Army Corps of Topographical Engineers. During their work, they may have passed quite close to the McGee Ranch project area. In 1840, the Corps traveled through Spokane County, south to Lapwai and Fort Walla Walla. A diary kept by one of the members of this company recorded their travel along the Columbia. Following an Indian road, which passed the base of Rattlesnake Mountain, through the Cold Craek Valley, they "traveled about fourty [sic] miles and encamped near the head of a small coulee which runs toward the Columbia, emptying below Priest Rapids" (Parker 1979, p. 11).

With the region mapped it seemed only a matter of time before permanent settlements began to appear. In 1847, however, the Whitman "massacre" at Wailatpu 
put a temporary stop to such endeavors. The incident, which occurred at the Whitman mission near present-day Walla Walla, was one of many clashes between the land's original occupants and the intruding settlers. Military intervention and the ensuing battles made settlement within the region undesirable for a time.

As the years passed, talk of peace, a prominent military presence, and the construction of new wagon roads began luring settlers back through the region. In 1853 , the Longmire wagon train passed close to the study area. Breaking away from the Oregon Trail somewhere nsar present-day Pendleton, the Longmire group headed north to the Columbia. At the mouth of the Yakima River, they left the Columbia and followed the Yakima to the Horn. "From the Horn they went along the Indian road through Cold Creek to a place known in 1917 as E. F. Benson Ranch, just below Rattlesnake Springs" (Parker 1979, p. 12). At this place they stopped, not knowing which way to go. A group of Indians who had been following them for several days gave them directions to a fort. They headed off from that point but quickly became disoriented. Their exact direction of wandering is unknown, but eventually they returned to the Rattlesnake Springs area where they met a group of Arnerican soldiers who led them to Fort Steilacoom.

During the 1850s, the Columbia Basin region was eventually closed to settlement by military orders because of the unrest among the native groups. All around this area, settlements were growing rapidly, fueled by the Oregon Donation Land Claim Act of 1850. The Columbia Basin was reopened for settlement in 1859, when Congress ratified the treaty that extinguished Indian title to the land.

Although the area was officially closed to settlement, it is apparent that this order was partially ignored locally. Much of the area's first settlement focused around the river, as it always had. In 1847, the first steamship made its way above the mouth of the Yakima River. In 1856, cattle ranchers began making their way into the valley, taking advantage of the open range. By 1861,3 years after the region had officially been opened, White Bluffs was a small settlement on the east side of the Columbia River. It served as a stopping point for the many steamers making their way upstream. Its location made it a point for unloading and shipping goods inland, and it grew rapidly. By 1870 , however, White Bluffs' growth had slowed considerably and even declined because of the growth of other local communities. The establishment of wagon roads that by-passed White Bluffs also was a contributing factor to its decline. 
In 1876, despite the treaties with the Indians, a great deal of unrest still existed. The Indian wars of the previous decades were supposed to be over, but the events of 1878 showed there was still a lot of discontentment. For example, on 8 July 1878, Blanche and Lorenzo Perkins of White Bluffs staned for Yakima City' but were killed at Rattlesnake Springs by a small band of Indians from Oregon.

This time, however, the unrest did not slow the incoming tide of settlers. The Northern Pacific Railroad brought a line down from Spokane to Ainsworth, at the muith of the Snake River in 1883. Stock ranchers continued to fill the area with cattle and horses, so that by the early 1880 s the natural bunchgrasses were nearly gone. Overgrazing coupled with severe winters, which plagued the first few years of the decade, destroyed nearly $80 \%$ of the stock. The ranchers simply did not have enough food to hold the cattle over during the rough winters. As farmers realized the need to grow alfalfa to feed their stock, small dams and irrigation systems began appearing along the rivers. The need for growing additional animal fodder thus motivated the development of the irrigation canals. The irrigation systems that arose at the end of the 19th century changed the face of the Columbia Basin forever.

Increased agricultural potential attracted more settlers, who started developing the west side of the Columbia River. Previous settlement had focused more on the east side. The growing need for irrigation pushed forward the Yakima Irrigation and Improvement Co.(Y.I. \& I. Co.), which in 1892 commenced canal construction at the Horn of the Yakima River. The canal was to stretch from the headgates at the Horn to Kennewick. This resulted in the platting of Kennewick, as well as a small land rush, as peopie hurried to invest in property along the projected ditch. Also planned was a canal that was to stretch around the foot of Rattlesnake Mountain and continue northeast to the Columbia. Water right notices were filed at the Yakima County Courthouse. Shortly after, the Y.I. \& I. Co. went into receivership. Several other companies, with the backing of prominent local citizens, bid for the canal contracts. Some were built; others were partially constructed and left incomplete because of the financial panic of 1893 to 1896 , which caused companies to go broke and lessened investors enthusiasm. In her book about the area, Martha Berry Parker (1979 p. 19) describes the first Yakima River ditches. She says that:

The first Y.I. \& I. ditches were planned to irrigate the east slope the Rattlesnake and were evidently partly built, ....The second Y.I. \& I. ditch, headed at the Horn of the Yakima, is still in use on the south and west bank of the river....The third ditch, which Nelson Rich had the contract to build from the Horn to the 
Columbia, was evidently on the north and east side of the Yakima, and may have been the one refarred to as the 'old home ditch' in the 1904 Columbia Courier...part of it can be seen from Highway 240 on the Vantage cut-off, about a mile from town....The fourth ditch, important to the early town of Richland, was one under Nelson Rich's private ownership. It headed at the Yakima several miles below the Horn. This ditch was the one that Howard S. and W. R. Amon bought to boom the first town of Richland in 1905. All but the faintest traces of this ditch are gone.

By 1900, Pasco and Kennewick were becoming small cities. Farther north and west, however, settlers were still few and far between. In the Priest Rapids Valley, farmers could still consider themselves pioneers. Overall, the landscape had changed little since the passage of Lewis and Clark. Although the bunchgrasses were gone, cheat:grass and tumbleweeds were still absent. Travel still occurred on the trails and Indian roads via wagons or horseback. More growth, however, was soon to come.

In 1903, the Columbia Courier noted that "lumber was being hauled out to the surrounding country." The "surrounding country" included Horse Heaven Hills, Finley, the Lower Yakima Valley, and the Kennewick Highlands (Parker 1979, p. 39). In October 1903, a permanent dam was built across the Yakima at the head of the canal at Horn Rapids, ensuring a constant supply of water. The following year, the canal irrigated five times more land than it had the previous year. The development of the area in following years revolved around water and the control of water rights. The creation of new irrigation and water companies, construction of new canals and ditches, and procurement of desirable land adjacent to those canals were all important events in the first decade of the century. Improvement of transportation, both on the river and on land, was also a common theme for the decade. Strawberries, root crops, fruit trees, onions, and barley, were as commonly grown as the alfalfa hay that started the irrigation boom.

The area continued to develop and grow, bit by bit. As transportation improved, the areas around the small towns and cities became more populated. Farming became the mainstay of the region, the culmination of many irrigation projects. Although hard times affected the area during the Depression, the Columbia Basin was less hard hit than other areas. As long as the crops were good, the area prospered. World War II brought war-time rationing and the loss of loved ones, but nothing affected the region more than the events of 1943. 
On March 6,1943, letters began arriving at the homes of Priest Rapids Valley and Lower Yakima Valley residents, informing them that they had between 2 weeks and 3 months to evacuate their homes. Properties were condemned in the Hanford, White Bluffs, and Richland areas to make way for a new, secret war project. Though the people were paid market values for their land, they lost the investments of 50 years.

This government action directly affected the individuals still residing in the current project area. Families that may have inhabited the project area from the turn of the century and weathered the economic struggles of the Depression were forced to leave their farms. All structures in the area were torn down as part of the Hanford Site development. The artesian wells that had served the small homesteads were capped. The area, that had grown crops and fed livestock was now used for practicing maneuvers by the military. As a result of government take over, no permainent dwelling has existed in the area since 1943. Archaeological resources found in the project area clearly demonstrate this transition from pioneering endeavors to the Hanford Works Project. 


\section{CULTURAL RESOURCES OBSERVED}

In our review of the project area, 42 cultural resources were recorded, including 22 sites and 20 isolated artifacts. Only 2 sites and 3 isolates were prehistoric. Area use as represented by these cultural resources can be broken into separate periods of distinct land-use patterns (Table 1).

IABLE1 Land-use Patterns in the Project Area

$\begin{array}{ll}\text { Time Period } & \text { Land-use Pattern } \\ ? 4500-2500 \text { B.P. } & \text { Prehistoric hunting/collecting } \\ 1880-1900 \text { A.D. } & \text { Early settlement in Central Washington } \\ 1900-1915 & \text { Irrigation development era } \\ 1915-1943 & \text { Intense land use/ Depression/ ACE (a) acquires land } \\ 1943-\text { present } & \text { No settlement, military use, DOE (b) activity }\end{array}$

(a) U. S. Army Corps of Engineers.

(b) U. S. Department of Energy.

\section{PREHISTORIC SITES}

Two sites and three isolates found in the project area, described below, are prehistoric. Although the sites are small, they are important within a regional context because they represent an interior hunting adaptation or land use. This is significant because of a general dearth of sites documenting interior land use across the Hanford Site. (Locally, prehistoric sites are concentrated along the river, indicating an economy focused on exploitation of riverine resources.) The majority of previously recorded interior sites tended to be associated with rocky outcrops. These lithic scatters, situated within the shrub-steppe nowhere near permanent water, indicate use of a broader resource base. Site characteristics indicate area usage between 4000 and 2500 years ago, a period designated the Frenchman Springs Phase (Nelson 1969). Climatic change during this period altered the riverine environment, resulting in a disruption of previously stable adaptive strategies (Chatters 1989).

Environmentally, this period was colder and wetter than previous and subsequent times. Few sites of this age have been studied in the mid-Columbia region, so human response to this change is not yet understood. Inland sites dating from this period are especially rare. 


\section{BN462}

The site consists of a light lithic surface scatter located in an area characterized by broad rolling inland flats dissected by numerous northwest/southeast-trending dry washes. Lithic debitage consists of approximately seven tertiary flakes of CCS, primarily opal with a single flake of brown chert. This scatter is in proximity to isolate $\mathrm{HI}-91-040$, which is made from identical material. The debitage is consistent with the final shaping of a similar artifact.

\section{$45 \mathrm{BN} 463$}

The site consists of a light scatter of chipped stone (lithics) in a shallow blowout, situated in gently rolling hills. The terrain is characterized by hummocks and ephemeral drainages. Lithic debitage consists of approximately 30 secondary and primary flakes of cryptocrystalline silicate (CCS), principally petrified wood and a white chert. No features are present, and the site lacks diagnostic artifacts, making dating of the site difficult. The material and reduction technologies used, however, are consistent with the two diagnostic artifacts located (HI-91-039 and HI-91-040).

\section{H1-91-03.}

The isolate is the medial section of a biface (dart point or knife) made of CCS. Material is a mottled brown/red. Total length (base and tip missing) measures $4.7 \mathrm{~cm}$. Width is $1.5 \mathrm{~cm}$, and thickness is $1.5 \mathrm{~cm}$. Shape and style are reminiscent of Frenchman Springs ( 4500 to 3800 years B.P.) material, but the artifact is too fragmentary for a firm identification. It was found in an area characterized by broad inland flats crosscut by northwest/southeast trending drainages. The isolate lies in the bottom of one of those drainages, near the confluence of two smaller drainages.

\section{HI-91-040}

The isolate is a CCS projectile point fragment. The point is made of a white opal and has a lateral irnpact fracture. Shoulders are pronounced, with a straight to slightly contracting stem and a convex base. Overall length is $2.6 \mathrm{~cm}$. It is $1.0 \mathrm{~cm}$ thick (rule measurements). The style is similar to Frenchman Springs points described elsewhere (e.g., Nelson 1969, Leonhardy and Rice 1970, and Kennedy 1976). The isolate lies on the south slope of a drainage within the shrub-steppe. The terrain is generally flat, broken only by east/west trending drainages. 
Consisting of a single, brown cryptocrystalline silicate flake, this large tertiary flake may have been a spent core. It measures $3.3 \mathrm{~cm} \times 2.8 \mathrm{~cm} \times 0.6 \mathrm{~cm}$ (rule measurements). The isolate was found within a broad inland flat between two drainages.

\section{HISTORIC SITES}

\section{$1880-1900$}

No evidence of early settlement from this time period exists within the project area. Continuous occupation and subsequent rebuilding, however, may accol.unt for the lack of sites from this era. Additionally, earliest settlement within the Columbia Basin focused on the more desirable locations nearer the Columbia River. By 1900, Pasco and Kennewick were small cities, but settlement away from the river was still rare. A plausible theory is that interior settlement only took place after land became occupied or unavailable along the river. Whatever the case, the earliest signs of historic land usage in this rocale do not appear to pre-date the turn of the century.

\section{0-1915}

The first signs of historic settlement in the project area are associated with the development of large-scale irrigation. Wooden irrigation pipes and troughs can be seen across most of the project area. Also associated with the pipes are irrigation ditches. This method of irrigatior commenced in 1908 and began waning in popularity by 1914. Although we do not consider these features significant because of their ubiquitous nature, we are awaiting recommendations from the SHPO on this question. Many of these pipes are in advanced states of decay, and large portions have been scavenged for lumber and used during later periods for construction, but a few remain in good condition and have good context relative to small homesteads. An example of these pipes should be collected and properly curated to serve as a model of these historic features. Detailed documentation of an irrigation line with pipes, troughs, and joints should be made.

Only the following three sites contain artifacts placing them within the 19001915 time frame. 


\section{H3-24}

This site is a high-density scatter of domestic debris. The site's total area measures $14 \mathrm{~m}$ east/west $\times 6 \mathrm{~m}$ north/south, with several 3-m-diameter scatters. The scatter is composed of several hundred sanitary cans, evaporated milk cans, amethyst and cobalt glass fragments, glazed stoneware fragments, three TYDA PINKHAM medicine bottles, tobacco tins, and an alarm clock. The milk cans were made between 1908 and 1914.

\section{H3-30}

This is a homestead site, characterized by the presence of several collapsed outbuildings, a possible root cellar, the remains of a windmill, and an artifact assemblage that includes domestic and farming debris. Datable artifacts, which include milk cans and ceramic trademarks, indicate that the site was occupied from the turn of the century into the 1940s. Domestic debris includes brown glass fragmients embossed with "Purex" labels, canning jar fragments, and white earthenware and stonewaro ceramic shards. Farm-related items include an International Harvester hubcap, wooden irrigation pipes, chemical containers, and assorted metal objects. Dead trees surround portions of the area, outlining the original location of the domestic structure. Irrigation ditches crosscut the area surrounding this complex. The depression, which may be a root cellar dug-out, has an earthen ramp descending from the east side. The heaviest concentration of domestic debris surrounds this area. The general area of the site is $75 \mathrm{~m}$ north/south $\times 50 \mathrm{~m}$ east/west, although portions of the site lie outside that area, such as piles of wooden irrigation pipe. The size of the building depression is $10 \mathrm{~m}$ east/west $\times 5 \mathrm{~m}$ north/south.

The significance of this site rests in its representation of the period beginning at the turn of the century and continuing though the Great Depression. Although a large part of this site was destroyed during Hanford clean-up operations, the area surrounding the cellar is intact, as might be sub-surface features. Because the site is not associated with any of the many artesian wells that dot the surrounding landscape, it has escaped the destruction that was visited upon its nearby neighbors when those wells were capped. The cellar and its associated artifact concentration can provide important information about homestead reliance on processed versus home-made food stuffs. This may be doubly important given that this site was used during the Depression era when many families were leaving urban centers and returning to 
subsistence lifestyles. Very little is known, archaeologically, about this era since it has only recently become historic. It is true that these sites are very common, but that means that few are being preserved.

In addition to the cellar feature, this site is also unique because the artifact assemblage is equally composed of domestic and farming-related artifacts. This may help to illustrate the dual nature of homesteading (i.e., home and commercial venture).

In the same quarter section, we found a wagon axle (HI-91-035) and two trash dumps (hi-91-034 and HI-91-036). We believe they are associated with this site. The 1880 Government Land Office (GLO) map for this region shows a wagon road passing through this quarter section, very close to the axle and not far from the homestead.

H3-33

This site is a can dump consisting principally of evaporated milk cans. Employing a can chronology developed by the Bureau of Land Management (BLM) as a means of dating, it was determined that the site was used between 1903 and 1930. The BLM method relies on can height and diameter measurements that are taken to the nearest 16 th of an inch. The milk cans measure $215 / 16$ in. in diameter $\times 46 / 16$ in. high. Other items consisted of a hole-in-cap evaporated milk can measuring 2 15/16 in. in diameter $\times 35 / 16$ in. high, a quart-size hole-in-top can measuring 5 in. in diameter $\times 51 / 2$ in. high, a RAWLEIGH'S bottle, a McCannon's Co. Winona, Minn., medicine bottle, and a brown pint, stoppered Clorox bottle.

\section{$1915-1943$}

Nearly all the remaining historic sites located during this survey fall within this time period. Small homesteads located at each of the artesian wells were growing at this time. Associated garbage dumps and effects of farming-related activities mark the landscape. Although some of these sites may only have been occupied during the 1930s, the nature of the dateable artifacts makes it very difficult to draw the line; hence, this is a very broad category. Specific dates and means of dating are included, therefore, in each site discussion.

\section{H3-23}

This site consists of five semi-subterranean structures and associated debris, built/excavated into the banks of a broad, dry, drainage. The structures have been 
numbered consecutively beginning on the south bank and working east. Two structures are intact (2\&3), two have collapsed (1\&5), and structure 4 has burned (Figure 3). Four structures are on the south bank of the drainage, and number 5 is on the north bank near the remains of a small stock pen. The structures were built by digging a rectangular pit into the bank and lining the back and sides with lumber scavenged from wooden irrigation pipes and troughs. A roof and front with a door completes each structure. The western walls extend out beyond the bank to form a. wind break (Figure 4). Structure 2 has a stove pipe outlet lined with tin sheeting. The two standing structures are full of tumbleweed, making entry difficult. Built-in shelves and hanging hooks are visible from the doorways.

Associated artifacts include liquor bottles, milk cans (3 14/16 $\times 2$ 15/16), blue glass canning jars, lard buckets, key and strip coffee cans, enamel cooking pots, bed springs, a wash basin, and utensil handles. These artifacts help to confirm that these structures are dwellings and not storage facilities. A date obtained from a single milk can (1917-1929) may not reflect the actual length of time the site was occupied. All bottles present were produced with an automatic bottle machine (1920 - present). Although the other artifacts are not specifically datable, they are, nevertheless, consistent with an early 1930's date.

Because the site appears to date from the Depression era and demonstrates a unique habitation style, it has great potential for illuminating some of the adaptive strategies used during this highly significant period of our country's history. The Great Depression of the 1930s was a period of population movement, coupled with rediscovery of subsistence-oriented lifestyles. Living in semi-subterranean structures could be a previously unrecognized chapter of life in this area.

Further investigation of this site is necessary to ascertain the cultural group responsible for these structures. It is unclear if these were Native Americans, white immigrants, displaced locals, or sheepherders. Research indicates the structures are not consistent with those used by Basque people, who are the predominant sheepherders in the region. The Basques did not arrive in the area until the later 1940 s and tended to maintain their practice of living in wagons and trailers as they tended flocks. 


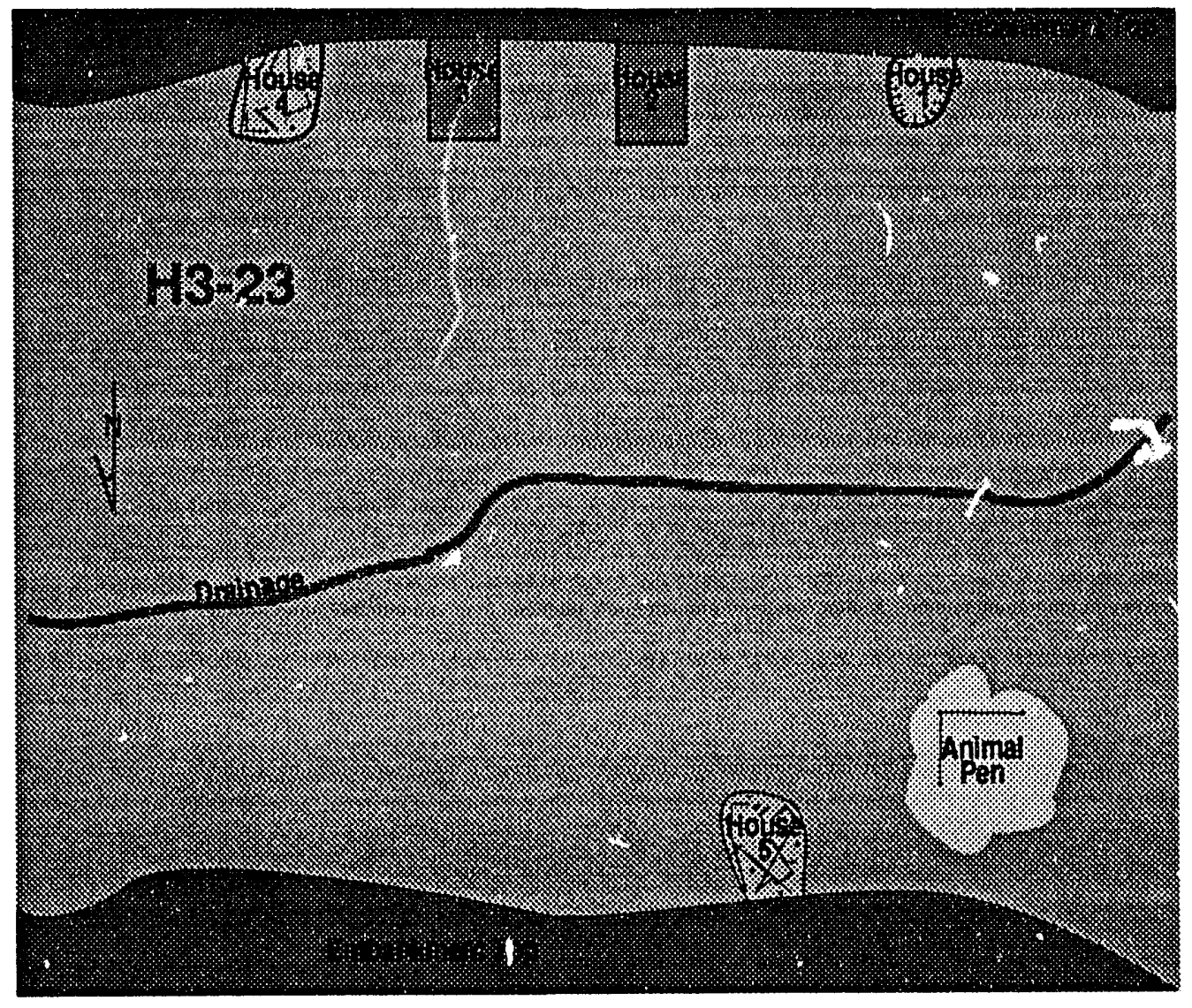

FIGURE 3. Map of Dwellings, Site H3-23

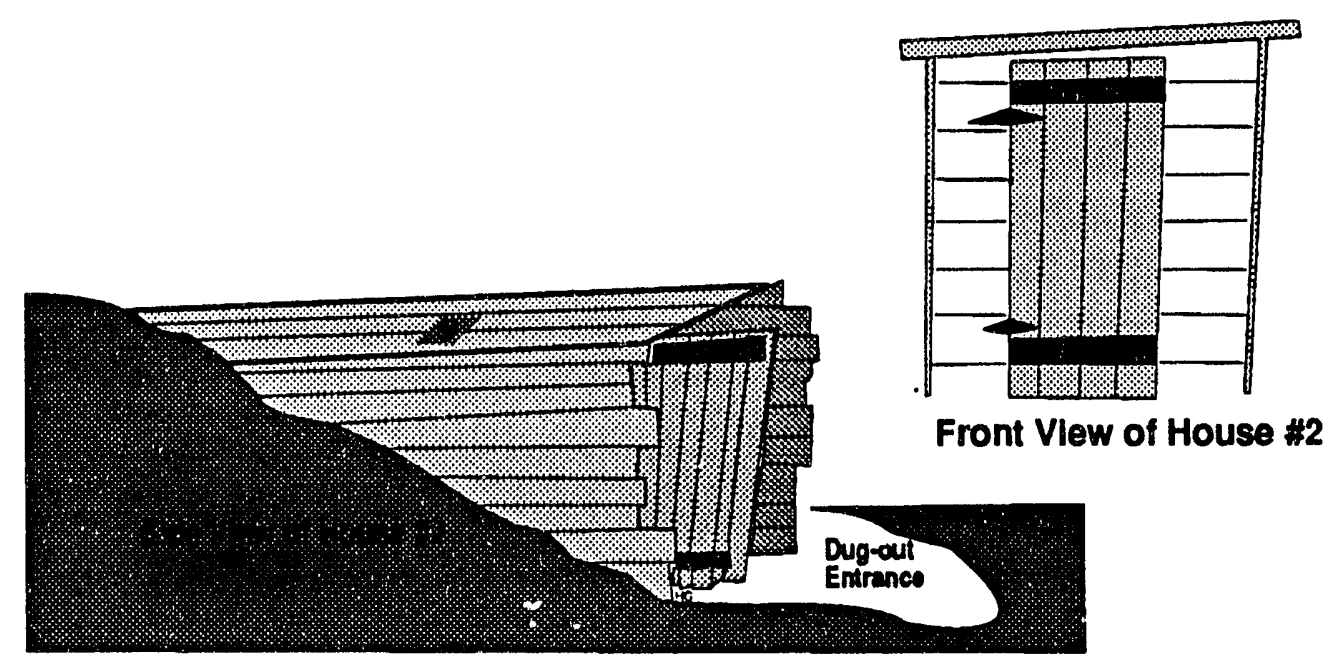

FIGURE 4. Detail of Structures, Site H3-23 
This site is a low-density scatter of domestic debris. The surface scatter extends $15 \mathrm{~m}$ east/west and $5 \mathrm{~m}$ north/south. Within that area are found sanitary and evaporated milk cans, glass fragments, ceramic fragments, tobacco tins, and coffee cans. There are no observed features associated with this site. Milk cans measuring 2 $15 / 16$ in. $\times 3$ 14/16 in., manufactured between 1917 and 1929, were found.

H3-26

This site is a low-density scatter of domestic debris, measuring approximately $25 \mathrm{~m} \times 25 \mathrm{~m}$. Artifacts obs эrved include sanitary cans, evaporated milk cans, glass fragments, and a headlamp from a 1920s or 1930's automobile. Cans found within the site were made between 1917 and 1929. The site lacks sufficient context and peripheral associations to illuminate broad histo ic patterns or provide specific information.

\section{H3-27}

This site consists of a single semi-subterranean structure, a chicken coop, covered cistern, and associated debris (Figure 5). The house is built into the bank of a broad, dry, drainage, and is similar in design, construction, and materials as those described for site $\mathrm{H} 3-23$. The house measures $3.0 \mathrm{~m} \times 3.7 \mathrm{~m}$ and features a windbreak on the west side and built-in shelves and hanging supports inside. The floor is dirt. The chicken coop measures $2.5 \mathrm{~m} \times 4.6 \mathrm{~m}$ and is constructed upon a nowcollapsed raised-rock foundation. Milled lumber, hog wire, and large-diameter chicken-wire forms the enclosure and flooring, while old wooden packing crates are used as nest boxes. The cistern is typical for the area, with a round cement-lined pit over $2.0 \mathrm{~m}$ in depth (currently filled with tumbleweed). It is capped by a milled-lumber cover and is surrounded by a chicken-wire fence. Wire nails are used exclusively throughout the structures, and all wood appears to have been scavenged from the wooden irrigation troughs and pipes; a large, scattered pile of these boards is located up the bank to the west of these buildings. Very little domestic debris is associated with the complex given its extensiveness; a sheepherder's stove, several sanitary cans, and a gasket-sealed Mason jar neck were the only readily apparent artifacts. The remains of several chicken-wire fence lines emanate from this lorale. No datable artifacts were directly associated with this site; however, dump site H3-42 may be 


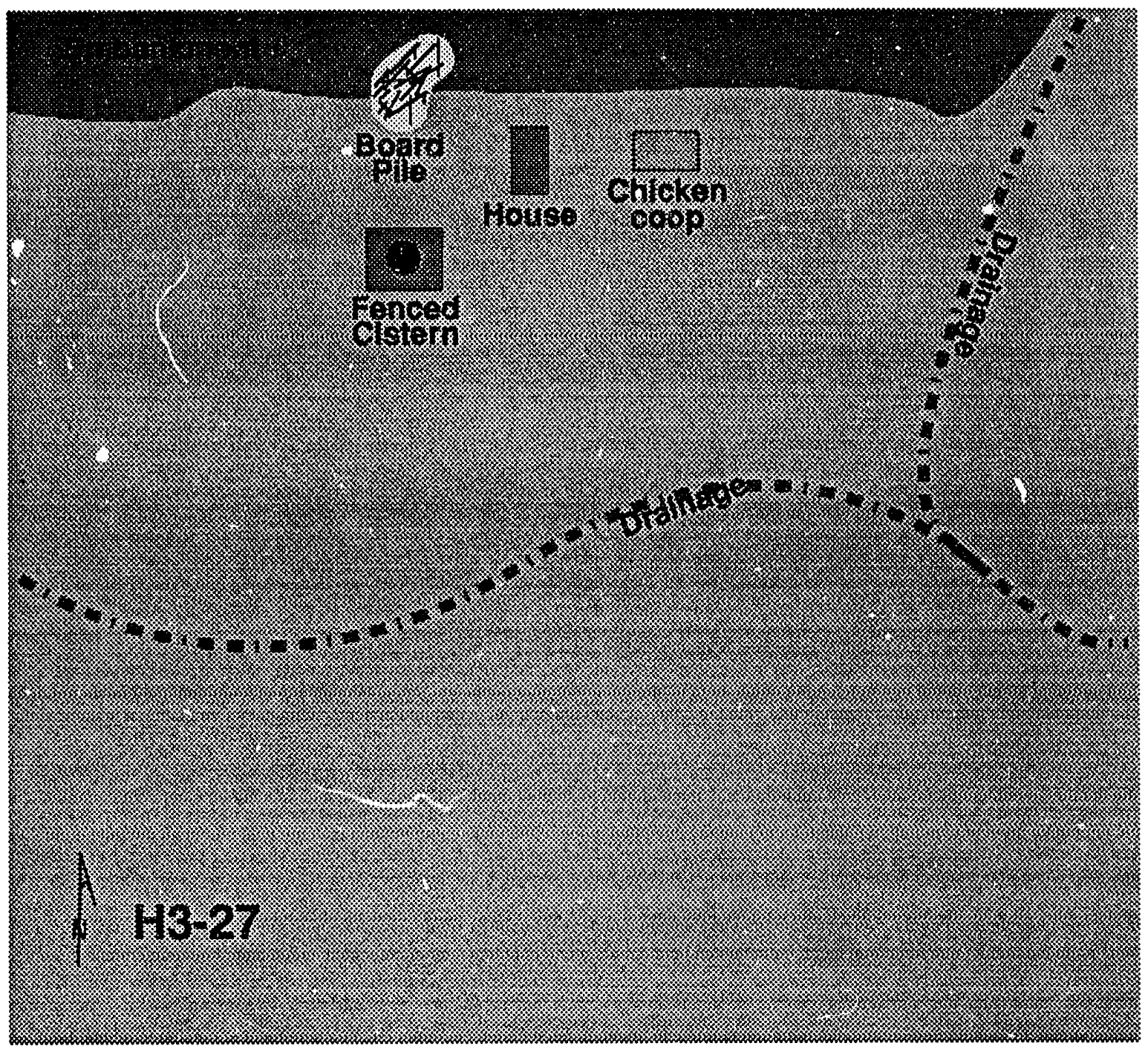

FIGURE 5. Map of Complex, Site H3-27 
associated with this site. Given $\mathrm{H} 3-27$ 's similarity to $\mathrm{H} 3-23$, the estimated site date is 1920 to 1930 s.

As with $\mathrm{H} 3-23$, this site is considered significant because of its potential to yield information regarding the Depression era. Because this era has only recertly been considered historic, little research on this topic has been completed. Therefore, any information these sites may reveal will contribute a great deal to our general knowledge of this time period and about a unique architectural style.

\section{H3-28}

This is a dump site, measuring $10 \mathrm{~m} \times 10 \mathrm{~m}$ and consisting of cans, glass bottles, a metal lamp fixture, stove top and pipe, and other domestic debris, as well as gears and pistons. Milk cans dated the site at 1915-1930. The general size of the site and relative density suggests that this collection of debris represents a single episode of dumping.

\section{H3-29}

This site is a single locus dump of domestic trash consisting largely of cans. Besides the sans, the site also contains, canning jar fragments, a metal lunch box with a gabled lid, stove pipe segments, a doorknob set, a muttin tin, lard buckets, and earthenware fragments. The site measures $16 \mathrm{~m}$ north/south $\times 12 \mathrm{~m}$ east/west. Milk cans date the site roughly between 1915 and 1930

\section{H3-31}

This is a light density debris scatter within $20 \mathrm{~m}$ south of a modern can dump. Debris is composed of large and small sanitary cans, evaporated milk cans, stoneware crockery fragments, fragments from an amethyst glass jug, and aqua and cobalt glass fragments. Milk can typology places the date of this site between 1917 and 1929.

\section{H3-32}

The site consists of a light scatter of domestic debris extending into a creek bed. The only structure observed was an outhouse. The site measures approximately $30 \mathrm{~m}$ east/west $\times 20 \mathrm{~m}$ north/south for total site area of $600 \mathrm{~m}^{2}$. The outhouse is of similar construction to others located within this area. There are no walls or roof, just a rectangular pedestal made of tongue-and-groove lumber. The hole covers are 
constructed from the opening cut-outs. The outhouse may be a military item designed for use within a tent and subsequently deposited on the site. Associated artifacts include amethyst glass fragments, evaporated milk cans, small medicine bottles, liquor bottles, a galvanized basin, stoneware crockery fragments, and a galvanized bucket. The milk cans place the date of the site between 1917 and 1929. The amethyst glass also supports this date.

$\mathrm{H} 3-34$

This site is a can dump located in a small drainage. The majority of the items are evaporated milk cans, several lard buckets, and syrup cans. Can size is $215 / 16$ in. $\times 4$ 4/16 in., providing a manufacturing date between 1917 and 1929.

$\mathrm{H} 3-35$

This site consists of a trash dump located in a low-level drainage. Items consist of evaporated milk cans, a galvanized pail, lard buckets, baking soda cans, a baking powder can, enamelware, kerosene cans, medicine bottles, pop bottles, and a wash tub. The site measures $60 \mathrm{~m}$ east/west $\times 30 \mathrm{~m}$ north/south. A milk can in the dump was manufactured between 1917 and 1929.

H3-36

A small can dump consisting of 10 or more steel beer cans and 8 or more sanitary cans. A single tobacco tin and a single key and strip can were also noted. The site covers roughly $15 \mathrm{~m}^{2}$. Based on identification of the beer cans, the site's date was estimated to be between 1935 and 1940.

$\mathrm{H} 3-37$

This site consists of a large can dump with two loci, each measuring approximately $6 \mathrm{~m}^{2}$. Both domestic and automotive artifacts are represented. Artifacts present include several hundred sanitary cans (many bayonet opened), one hole-andcap can, evaporated milk cans, glazed stoneware crockery fragments, engine pistons, blue bromide bottle glass, Mason jar glass, kerosene drums, buckets, a glazed coffee pot, barrel hoops, and a stove pipe. No structural remains were noted. The source location for this material was not located. The debris may have been transported in bulk to this location from a homestead elsewhere. The mixed variety of material from 
various dates (e.g., hole and cap can from late 1800 s mixed with others from the 1920 s and 30s) suggests a "clean-up" operation.

\section{H3-38}

This historic homestead, characterized by corrals, has a well-preserved outhouse with modern improvements (paper dispenser, urinal), a grove of trees, and a scatter of domestic and farm artifacts. The remains of a wooden irrigation system are also evident. Possible collapsed outbuildings are present around the site perimeter. The core of the site measures roughly $100 \mathrm{~m} \times 100 \mathrm{~m}$.

Artifacts observed include glass fragments, brown-glazed, red drain tile fragments; sanitary cans; ceramic fragments; clear glass jar fragments (one Owens Illinois trademark); Mason canning jars; mechanical tools; pink carnival glass; and paint cans. Cans were manufactured between 1935 and 1945. Fencing around the site is mostly $10-\mathrm{cm}$ mesh stock fencing rather than barbed wire.

The site's integrity was destroyed when the area was abandoned and the current well was capped. Bulldozer marks can be clearly seen over the entire area, and the topsoil appears very mixed. Given this loss of integrity, the site can offer little information about homestead life or answer regional questions about settlement and land usage.

H3-39

This is a trash scatter largely consisting of domestic debris such as cans and glass. The size $\left(32 \mathrm{~m}^{2}\right)$ and density of this collection suggests that it represents a single episode of dumping. A milk can found at the site was manufactured between 1917 and 1929.

$\mathrm{H} 3-40$

This historic site includes a cellar depression and a cement-lined cistern. There is a relatively light scatter of domestic debris, including sanitary cans, evaporated milk cans, ceramic fragments, and glass fragments. Milk cans date the site between 1917 and 1929. A ceramic trademark indicates that the site was used through the 1930s. 
Overall site dimensions are $10 \mathrm{~m} \times 10 \mathrm{~m}$. The cellar depression is $7 \mathrm{~m} \times 6 \mathrm{~m} \times 2$ $\mathrm{m}$. The wood-covered, cement-lined cistern is $1.5 \mathrm{~m}$ in diameter. It has a current depth of $2 \mathrm{~m}$.

\section{H3-41}

A historic homestead, this site consists of a grove of trees, a building foundation and depression, fences, and a domestic assemblage of antifacts. The integrity of the site was destroyed when the artesian well was capped. The remnants of the earlier well can be seen to the east of the modern well. Artifact concentrations appear to have been created by earth-moving activities associated with capping the well. Rows of trees are likely indicators of the original location of the dwelling structure, which sits at the edge of a drainage. The fence system extends away from the main area, as do the irrigation ditches.

The artifact assemblage is mostly glass or ceramic shards. There are very few cans present for a site this size, which may indicate that a larger dump site exists nearby. The only datable artifact is the neck of a bottle produced with an automatic bottle machine, a technique that was first used in 1920.

\section{$\mathrm{H} 3-42$}

This site is a fairly dense scatter of domestic debris. A large portion of the site is obscured by Salsoa; however, the deposit appears to be consolidated with welldelineated borders. A slight depression was used as a dumping site. Objects found within the scatter include several hundred cans and jars (principally sanitary cans, evaporated milk cans, and Mason jars), tobacco tins (Prince Albert), liquor bottles, and carbon batteries (arranged in rectangular rows). On the basis of the milk can typology, the site was given a date of 1917-1929.

This site may be associated with the dug-out and chicken coop complex H3-27, which is approximately $100 \mathrm{~m}$ to the south. The age of the material is coterminous, and domestic debris was surprisingly absent from the immediate vicinity of that dwelling. A regularly used dump would suggest fairly long-term habitation of the site. Given this potential association with $\mathrm{H} 3-27$, this site has significance. In context with the habitation site, this dump may yield information about subsistence practices during the Great Depression. 


\section{3 - Present}

Although this period is not historic under the NHPA, it nevertheless represents a distinct period of land use. There was no permanent occupation within the project area during this period; however, the military used the area for maneuvers. Evidence of their presence forms the single most pervasive artifact assemblage within the project boundaries. For example, $\mathrm{C}$ ration cans litter the landscape, both singly and strung on lines of wire to form camp "alarms." Communication wire also crisscrosses the area, creating an ever-present tripping hazard. Less common, but providing an earliest date for the military presence, are both spent and unfired cartridge blanks of .223 and .308 caliber. The U. S. Military did not replace the .30 caliber with these rounds until 1956. Other munitions found were intact belts of .50 caliber machine gun blanks, spent gas marking grenades, containers for $105-\mathrm{mm}$ howitzer ammunition, and assorted pieces of shrapnel from both artillery and air-dropped ordinance. Several large piles of tangle wire were found, the majority of which are in the bottom of dry washes. The military also left behind no less than 3 outhouses of excellent craftsmanship (see descriptions for HI-91-26 and HI-91-27). Also observed were personal items lost or discarded by the troops such as flash lights, metal mirrors, bundles of tent cord, and stakes.

Because this material is less than 50 years old it is not considered historic, and, therefore, military items were only noted and not recorded. Two outhouses, HI-91-26 and $\mathrm{HI}-91-27$, are exceptions, as these were recorded before their military origin was recognized.

\section{ISOLATED HISTORIC CULTURAL RESOURCES}

In addition to the cultural resources described in this section, isolated artifacts that appeared to be over 50 years of age were also noted. Only a few of these items are datable. Apart from $\mathrm{HI}-91-034, \mathrm{HI}-91-035$, and $\mathrm{HI}-91-036$, which were discussed regarding their possible relationship to homestead site $\mathrm{H} 3-30$, these isolated finds cannot be positively associated with any particular site. With the possible exception of a few cans and the wason axle, most of these finds seem to fit within the 1915-1943 timeframe. Brief descriptions of these artifacts follows in Table 2. 
IABLE2. Isolated Artifacts Recorded within the McGee Ranch Project Area

Number Description

HI-91-020 - Two solder seam, "hole in cap" cans.

HI-91-021 - A 1 gal. solder sealed can with crimp attached lid.

HI-91-022 - A piece of towed farm machinery called an "Automatic Land Leveler in. Made by Eversman MFG. Co., Denver Colo." Pats. 1469502 and 1765910.

HI-91-023 - An oval, milk glass, Ponds hand cream jar.

HI-91-024 - A Cone-top beer can.

HI-91-025 - An evaporated milk can (2 15/16 in. diameter. $x 4$ in. high), made between 1917 and 1929.

HI-91-026 - A 10-hole outhouse frame, with five receptacles per side. Frame measures $9 \mathrm{ft} 81 / 2$ in. $\times 4 \mathrm{ft}$, and is made using a tongue-andgroove construction. Each seating arrangement would have been covered by a hinged, wooden lid; only one remains intact. The outhouse is pedestal only, lacking walls and a roof. This appears to be a military item, designed for use within a tent.

HI-91-027 - An outhouse seating frame, measuring $3 \mathrm{ft} .4$ in. $\times 8 \mathrm{ft} 1$ in., with four in-line seating arrangements. Made with tongue-and-groove construction, the outhouse is pedestal only. Like HI-91-026, this may be a military item.

HI-91-028 - A whiskey bottle produced with an automatic bottle machine. "TANLAC" on base, cork seal. Associated with several severely rusted cans.

HI-91-029 - A very small scatter of green and white glass and white glazed stoneware. Stoneware trademark - "Radisson, W.S. George." Also associated was a spice can and a John Deere cap.

HI-91-030 - A light scatter of stoneware crockery fragments and a broken cobalt bromide bottle.

HI-91-031 - A wash tub lid, oval-shaped, steel.

HI-91-034- An evaporated milk can measuring $215 / 16$ in. $\times 4$ in., manufactured between $1917-1929$.

HI-91-035 - A wooden wagon axle with iron fittings, with one wheel hub fractured which may account for its abandonment. Associated with a wagon road shown on an 1880 G.L.O. survey map. 


\section{IABLE2. (cont.)}

\section{Number Description}

HI-91-036 - An evaporated milk can manufactured between 1917 - 1929.

HI-91-037 - The rear portion of a Model T Ford Automobile. Car seat springs were located near the body. A single wooden floor board was still intact.

HI-91-038 - A portion of a metal stove. Embossed on the front: "Leonard Hi......n Range Company Cedar Rapids, lowa 110". 


\section{CONCLUSIONS}

Between October and December 1991, PNL's HCRL conducted a literature review and archaeological survey of the McGee Ranch area. The project covered an area of 840 ha. Twenty-two sites and 20 isolates occur in the project area. Of the sites, 20 are attributable to Euro-American farming activity during the early twentieth century. Two isolates are from Native American occupation, dating around 4000 B.P. Although the two sites and remaining isolate are undated, they are technologically and materially similar to the diagnostic artifacts located.

Requests for Determination of Eligibility, Findings of Effect and Adverse Effect, and plans for mitigation of adverse effects to significant historic properties will be prepared and submitted to the Washington State Historic Preservation Officer, Advisory Council for Historic Preservation, and interested parties (including Indian tribes) on an as-needed basis.

\section{POTENTIALLY SIGNIFICANT SITES}

Determinations of Eligibility to the National Register must be obtained for all sites to be impacted by borrow pit activities; however, only sites determined significant by the SHPO will need further attention. We recommend that all prehistoric cultural resources be considered potentially significant. Because of their limited areal extent, mitigation procedures should prove to be minimal. Recommended mitigation would include surface collection, detailed mapping, and photo documentation. Limited subsurface testing would be conducted to confirm site boundaries.

Of the historic sites, $\mathrm{H} 3-23, \mathrm{H} 3-24, \mathrm{H} 3-27, \mathrm{H} 3-30, \mathrm{H} 3-40$, and $\mathrm{H} 3-42$ are considered potentially significant. They were selected because they are representative of their occupation period, have relatively good integrity, and have potential to contribute new information regarding the historic periods described.

Site H3-24, an extensive scatter of domestic debris, and H3-30, an early homestead, date to the turn of the century and are considered important because they represent some of the earliest settlement in this area. Although the areas along the river saw development as early as the 1870s, the inland region north of the Yakima River was still considered wild and unpopulated in 1900 . Settlers in these areas were rightly considered pioneers as late as 1910 . Site $\mathrm{H} 3-30$ is also potentially significant, not 
only for its representation of the period beginning at the turn of the century, but also because occupation continued though the Great Depression.

Although a large part of this site was destroyed during Hanford clean-up operations, the area surrounding its cellar is intact, as might be sub-surface features. Because the site does not have one of the many artesian wells that dot the surrounding landscape, it has escaped the destruction that was visited upon its nearby neighbors when those wells were capped. The cellar and its associated artifact concentration can provide important information about homestead reliance on processed versus homemade food stuffs. This may be doubly important given that this site was used during the Depression era when many families were leaving urban centers and returning to subsistence lifestyles. Very little is known, archaeologically, about this era since it has only recently become historic; therefore, any information obtained from this site will contribute a great deal to the general knowledge. Comparison of this site with sites H3-23 and H3-27 can provide contrasting information on depression era adaptations.

Sites $\mathrm{H} 3-23, \mathrm{H} 3-27$, and $\mathrm{H} 3-42$ are considered potentially significant because they date from the Depression era. H3-23 and H3-27 contain semi-subterranean dwelling structures, a unique habitation style. The Great Depression was a period of population movement and the rediscovery of subsistence-oriented lifestyles. Very little is known, archaeologically, about this period of American history. These sites have the potential to illuminate some of the adaptive strategies used during this highly significant period of our country's history. Living in semi-subterranean structures could be a previously unrecognized chapter. $\mathrm{H} 3-42$ is considered significant because it relates to H3-27. Given its proximity to that site $(100 \mathrm{~m})$, this dump site could reveal a great deal about the survival strategies of the dwelling's inhabitants. Ethnicity, subsistence strategies, and length of occupation could be determined from analysis of the dump's contents.

Further investigation of these sites is necessary to ascertain the cultural group responsible for these structures. It is unclear if these were occupied by Native Americans, white immigrants, displaced locals, or sheepherders. Based on research conducted to date, the structures were probably not constructed by Basque people, who are currently the predominant sheepherders in the region. "...only a few Basques had participated in the sheep business of the region before World War II, they had 
been extremely successful sheepherders and sheep owner in many other areas..." (McGregor 1982, p. 330).

H3-40 is considered potentially significant because of its similarity to the semisubterranean dwelling sites. This site has a cistern and a building depression. The artifacts present indicate that the site was coexistent with the other Depression-era sites. To what degree these sites may have been related remains to be determined. 


\section{BEFERENCES}

Chatters, J. C. 1989. Hanford Cultural Resources Management Plan. PNL-6942. Pacific Northwest Laboratory, Richland, Washington.

Kennedy, H. K. 1976. An Examination of the Tucannon Phase as a Valid Concept:

Step One. M. A. Thesis, University of Idaho, Moscow, Idaho.

Leonhardy, F. C., and D. G. Rice. 1970. "A Proposed Culture Typology for the Lower Snake River Region, Southeastern Washington." Northwest Anthropological Research Notes 4(1):1-29.

McGregor, A. C. 1982. Counting Sheep: From Open Range to Agribusiness on the Columbia Plateau, University of Washington Press, Seattle, Washington.

Nelson, C. M. 1969. The Sunset Creek Site (45KT28) and its Place in Plateau Prehistory. Anthropology Report Investigations No. 47, Washington State University, Pullman, Washington.

Parker, M. B. 1979. Iales of Richland. White Bluffs \& Hanford 1805-1943: Before the Atomic Reserve, $\mathrm{Ye}$ Galleon Press, Fairfield, Washington. 


\section{DISTRIBUTION}

No. of

Copies

\section{OFFSITE}

12 DOE/Office of Scientific and

Technical Information

Mary Thompson

State Historic Preservation Officer

Office of Archaeology \& Historic

Preservation

111 West 21st Ave., KL-11

Olympia, WA 98504-5411

Duane Hogan

U.S. Army Corps of Engineers

Box C-3755

Seattle, WA 98124-2255

Dennis Canty

National Park Service, Pacific

Northwest Region

83 King St., Suite 212

Seattle, WA 98104

John Leier

U.S. Army Corps of Engineers

Walla Walla District

Building 602, City-County Airport

Walla Walla, WA 99362-9265

Bruce Crespin

U.S. Bureau of Land Management

Burns, OR 97720

2 Colville Confederated Tribes

Attn: Tribal Council

Adeline Fredin

P.O. Box 150

Nespelem, WA 99155

$2 \quad$ Nez Perce Tribe

Attn: Tribal Council

Alan Slickpoo

P.O. Box 305

Lapwai, ID 83540
No. of

Copies

2 The Confederated Tribes of the Umatilla Indian Reservation

Attn: Tribal Council Jeff Van Pelt

P.O. Box 638

Pendleton, OR 97810

2 The Wanapum Indian Tribe

Attn: Tribal Council

Rex Buck Jr.

P.O. Box 275

Beverly, WA 99321

2 The Yakima Indian Nation

Attn: Tribal Council Bill Yallup.

P.O. Box 151

Toppenish, WA 98948

\section{ONSITE}

13 DOE Richland Field Office

C. R. Pasternak (5)

P. F. Dunigan

N. M. Highland

M. B. Hitt

R. D. Izatt

E.E. Pride

J. R. Shadel

R. K. Stewart

DOE Legal Library

31 Westinahouse Hanford Company

M. R. Adams

H. L. Benny

J. W. Cammann

R. A. Carlson

L. P. Diediker

R. H. Engelmann

G. C. Evans

M. C. Hughes

C. J. Kemp

A. R. Johnson

Dist. 1 
PNL-8186

UC-702

\section{DISTRIBUTION}

D. S. Landeen

J. G. Lindberg

S. M. McKinney

M. A. Mihalic

P. D. Mix

D. J. Moak

K. L. Petersen

R. C. Roos

M. R. Sackschewsky

S. W. Seiler

K. M. Singleton

W. A. Skelly

D. E. Skoglie

J. C. Sonnichsen

E. T. Trost

R. S. Weeks

N. R. Wing

J. F. Woods

J. G. Woolard

EDMC

IRM Clearance

28 Pacific Northwest Laboratory

J. C. Chatters

J. W. Falco

H. A. Gard (10)

R. H. Gray

J. M. Hales

P. C. Hays

R. E. Jaquish

J. G. Longnecker

R. M. Poet

W. H. Rickard

L. E. Rogers

R. L. Skaggs

M. K. Wright

Publishing Coordination

Technical Report Files (5)

Dist. 2 

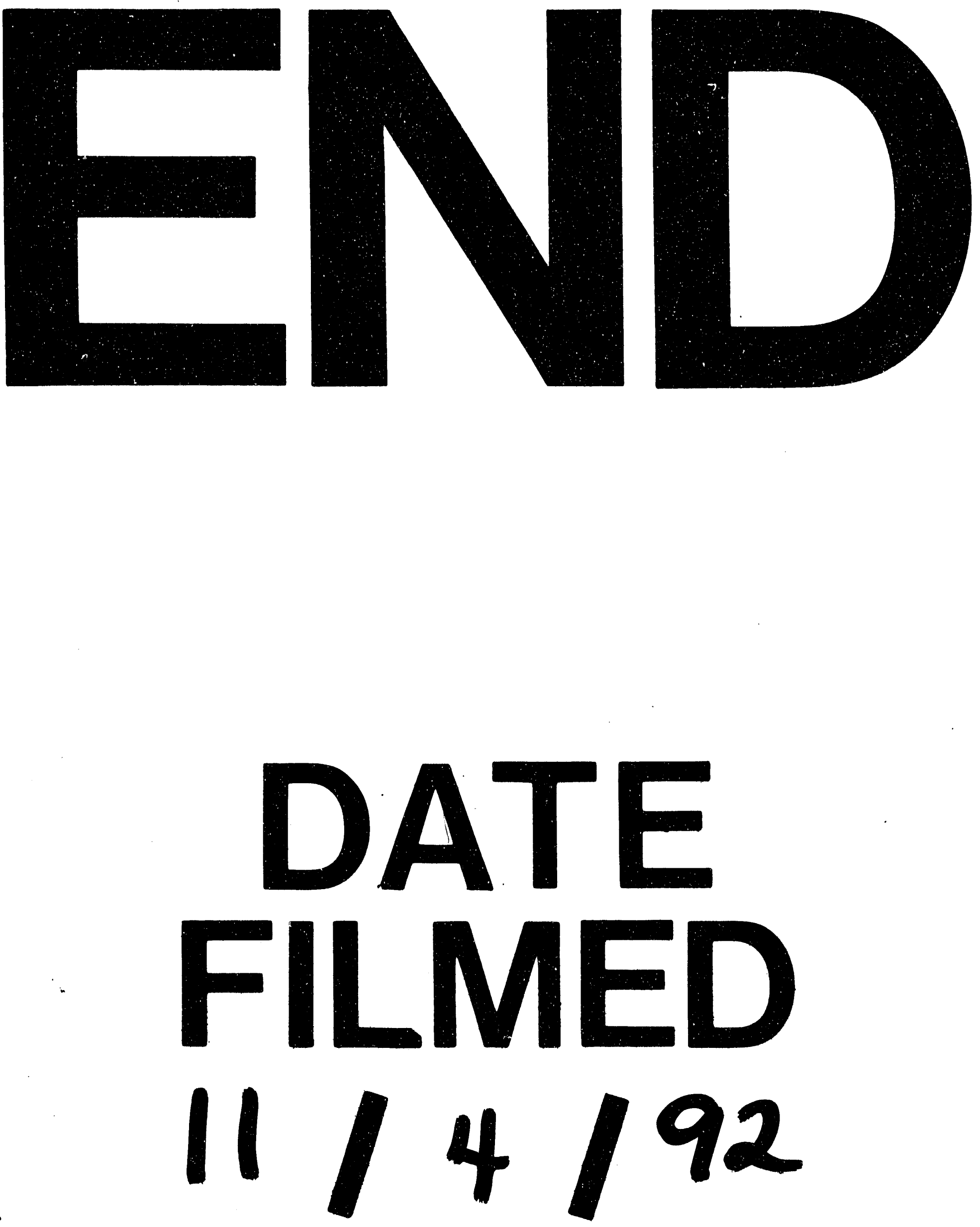

1 
